Supporting Information: Copies of NMR spectra 2

\title{
Synthesis of Amine-Borane Intramolecular Complexes through \\ Palladium-Catalyzed Rearrangement of Ammonioalkynyltriarylborates
}

Naoki Ishida, Mizuna Narumi, and Masahiro Murakami*

Department of Synthetic Chemistry and Biological Chemistry, Kyoto University,

Katsura, Kyoto 615-8510, Japan 


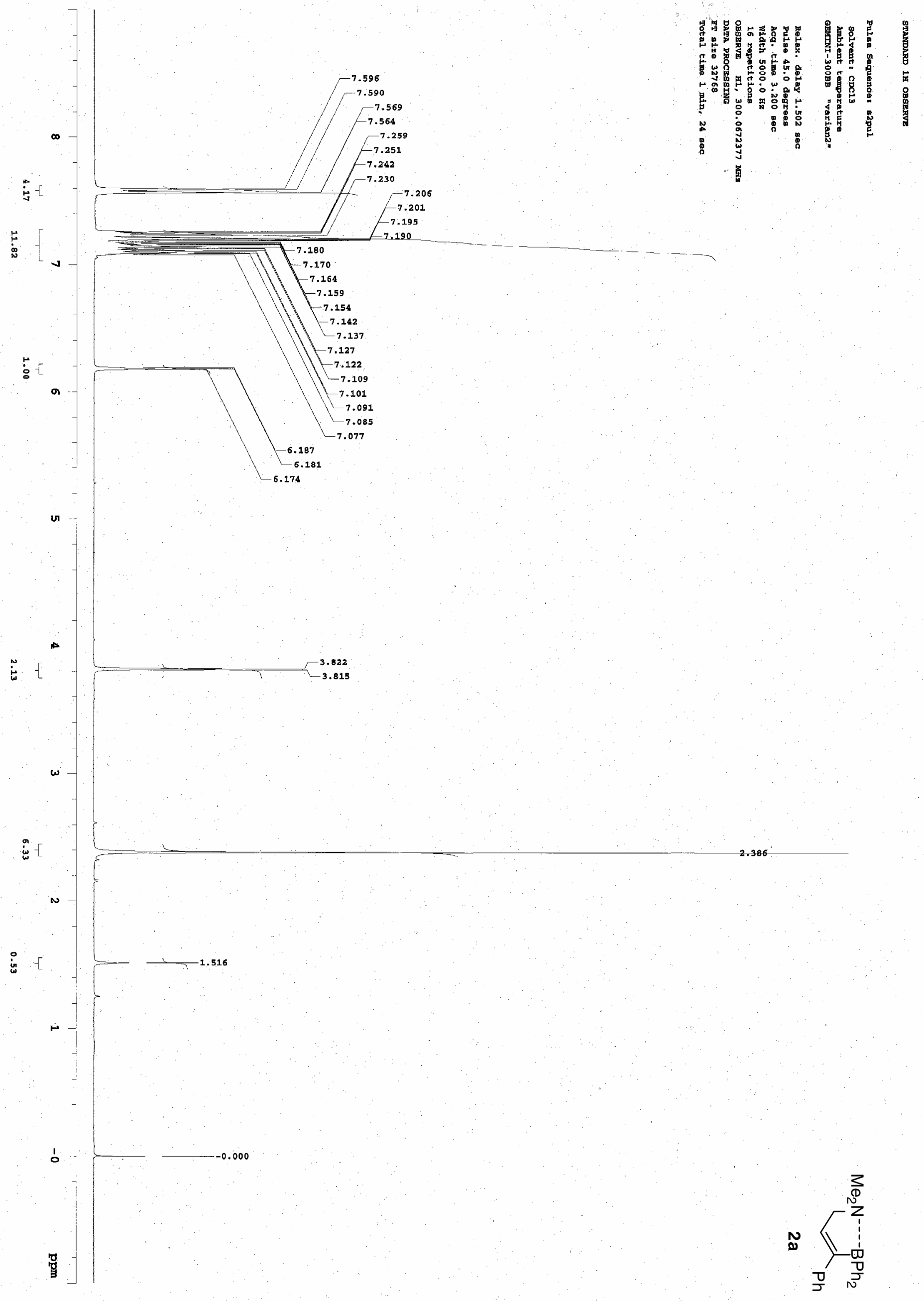



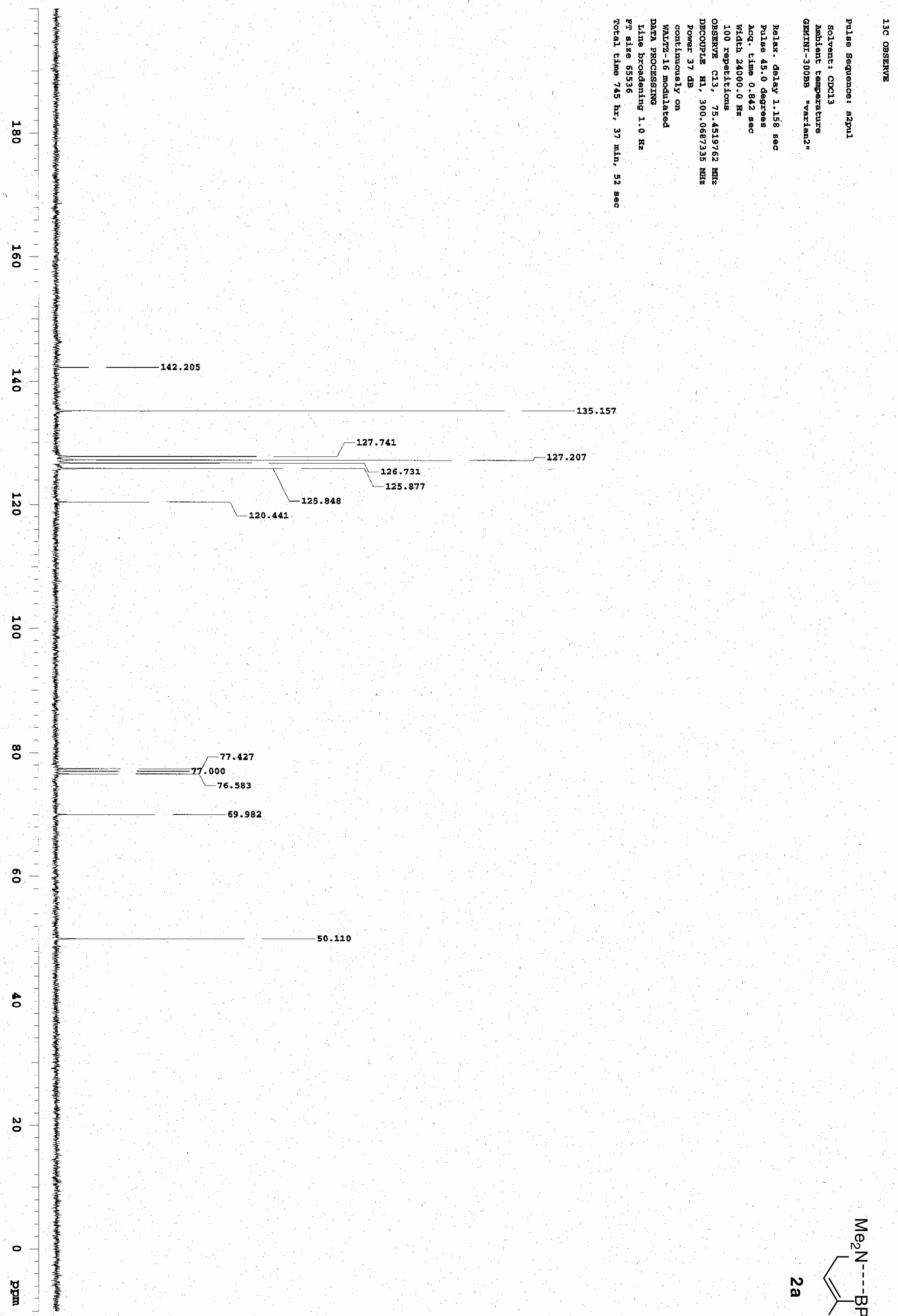


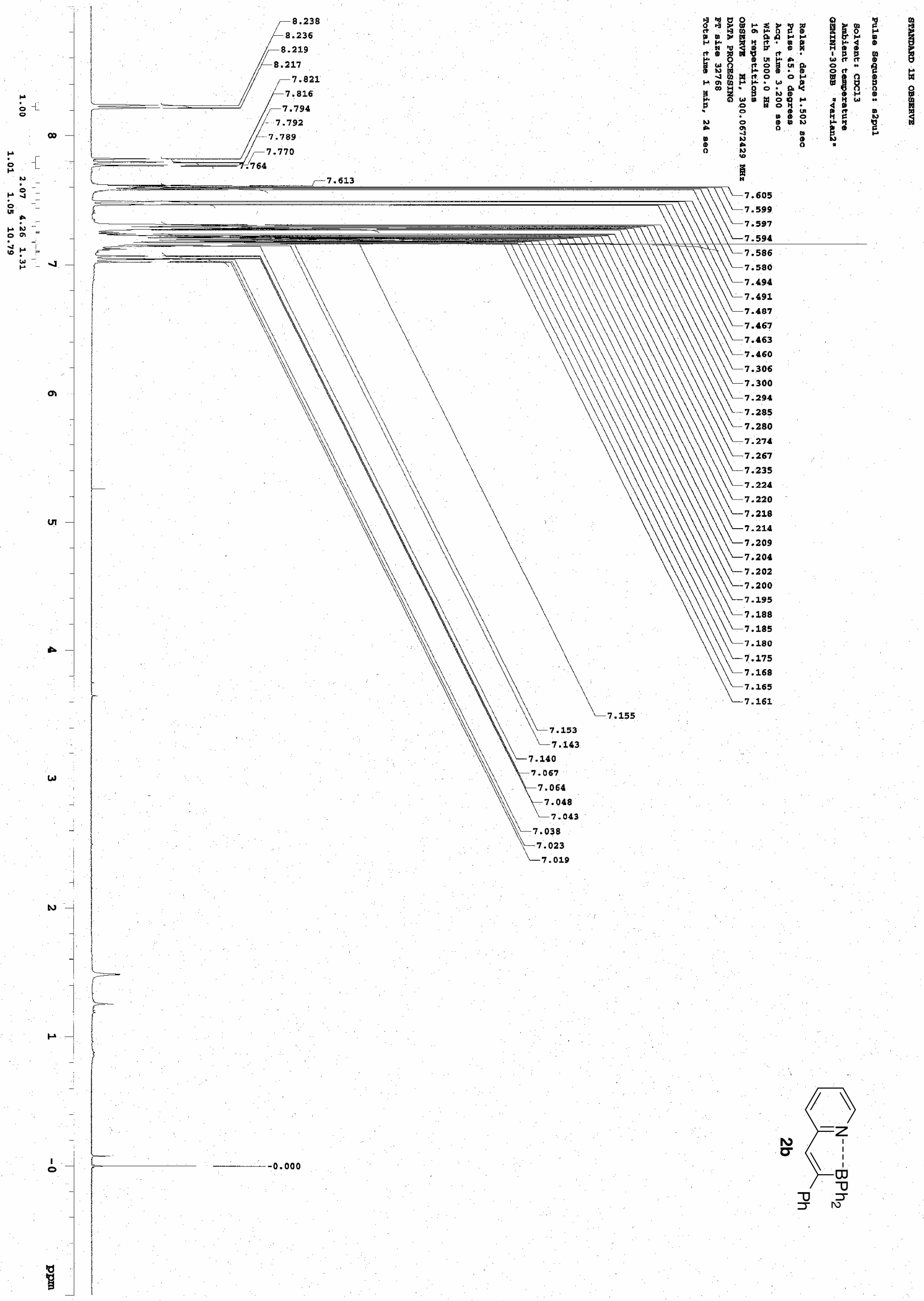




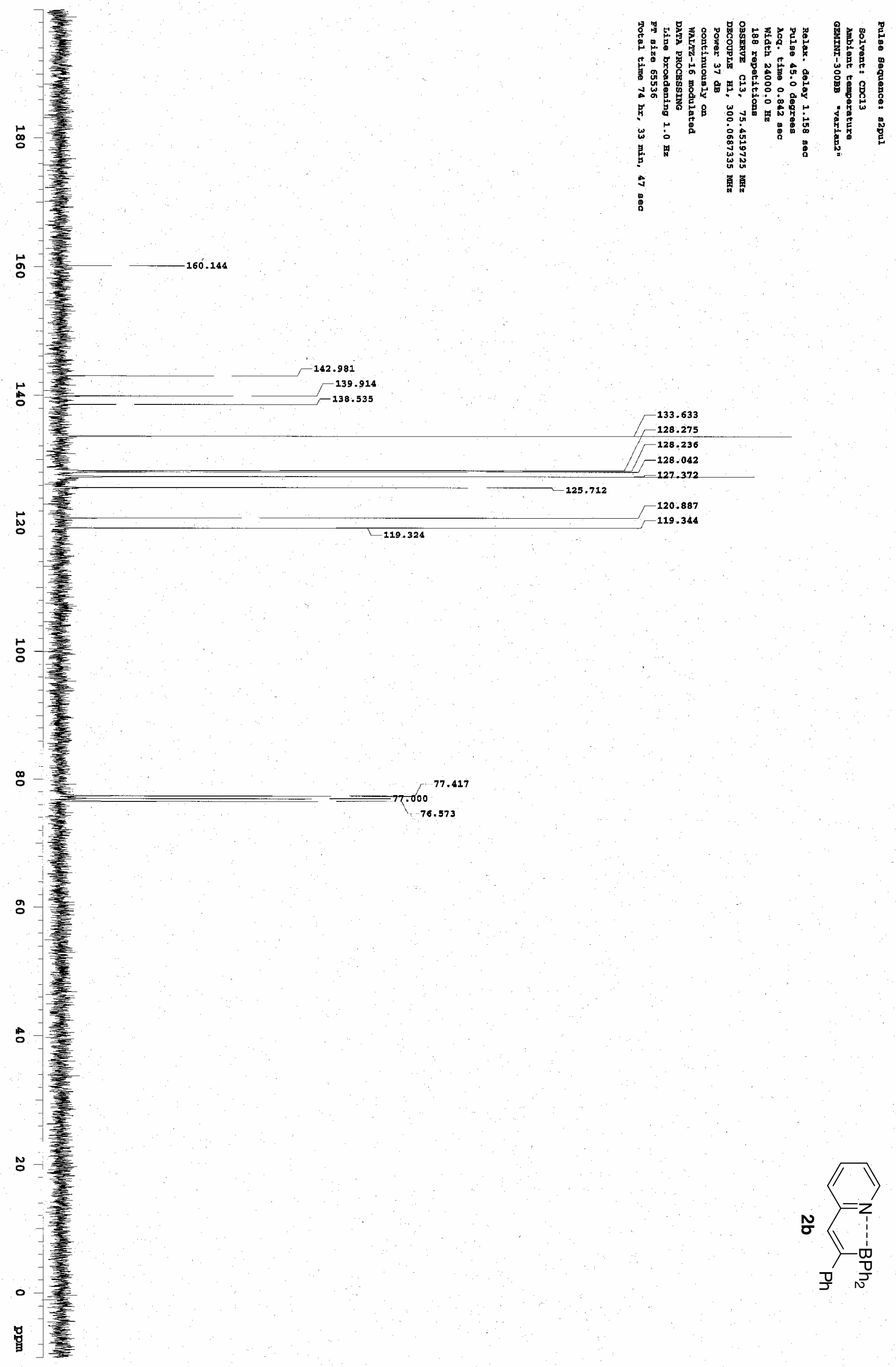




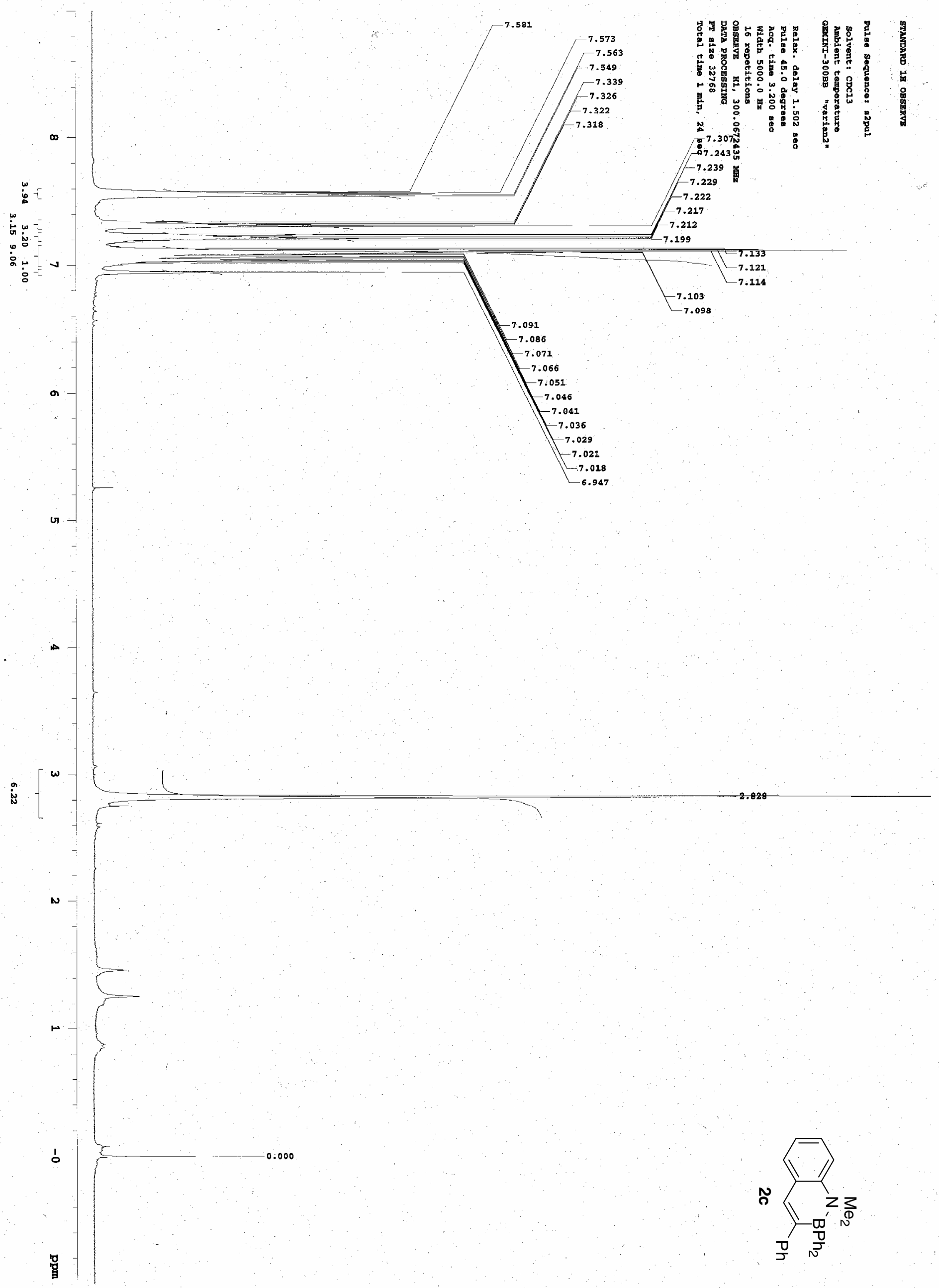




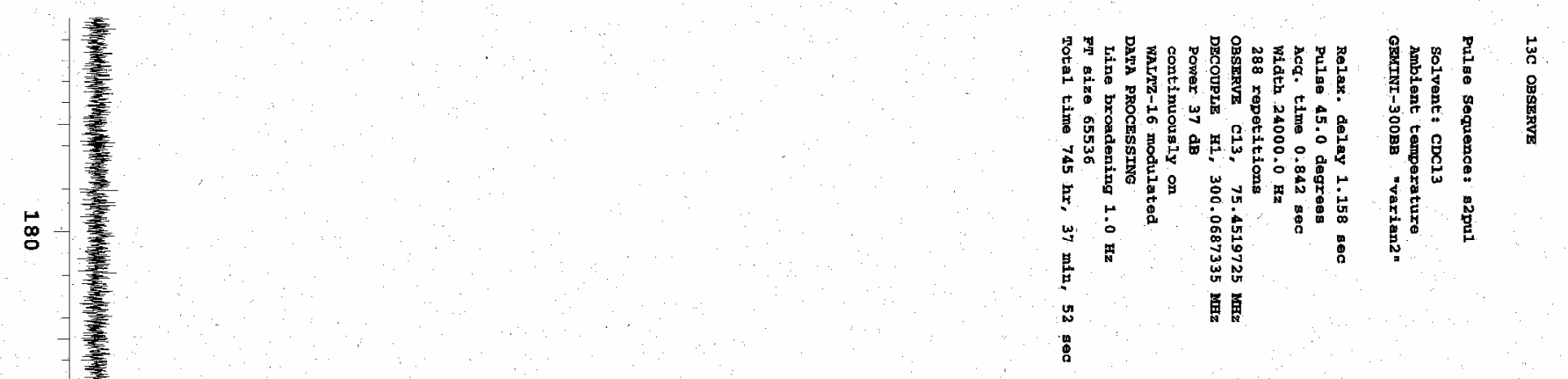

응

\&

136.681

$\Gamma^{129.731}$

128.061
-127.964

芯

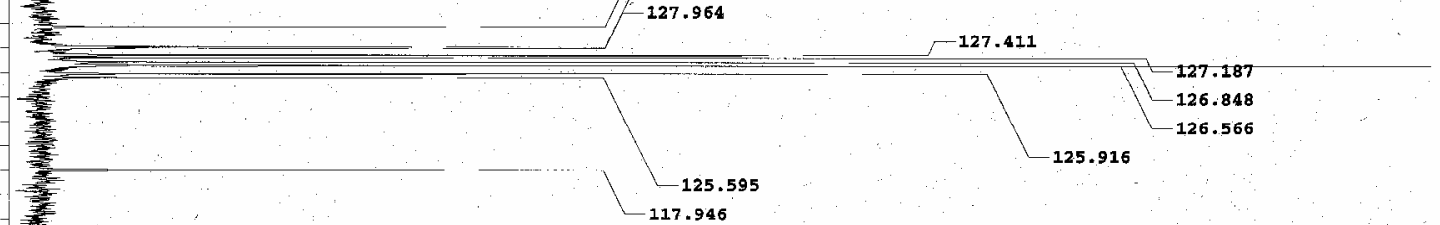

용

ร

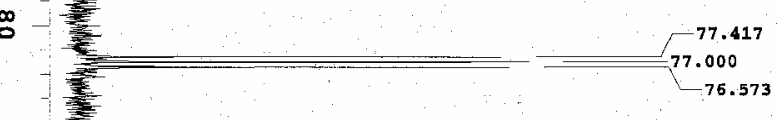

\&

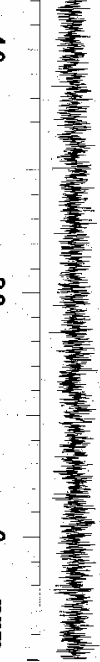

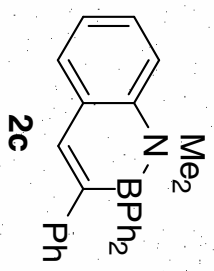




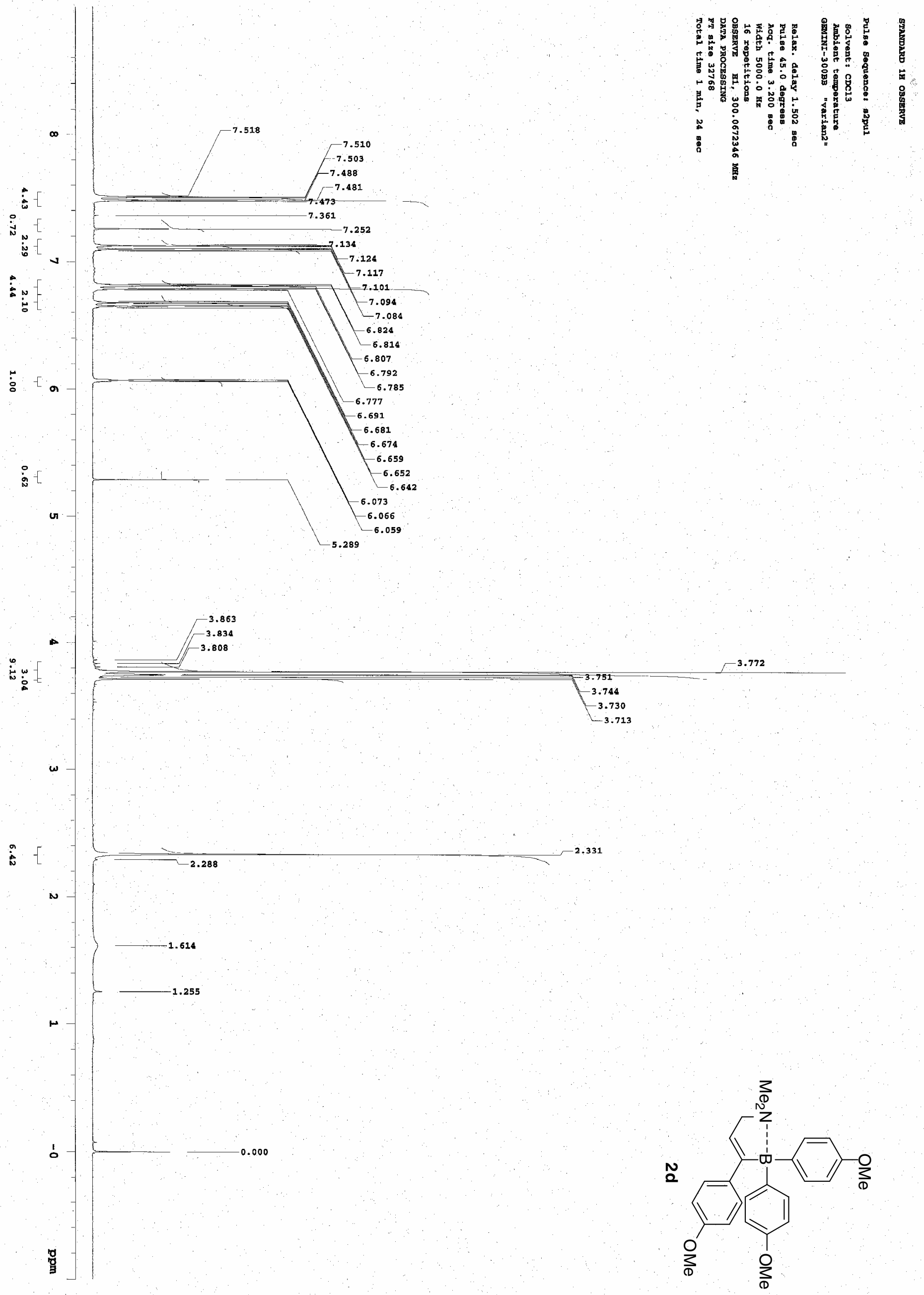




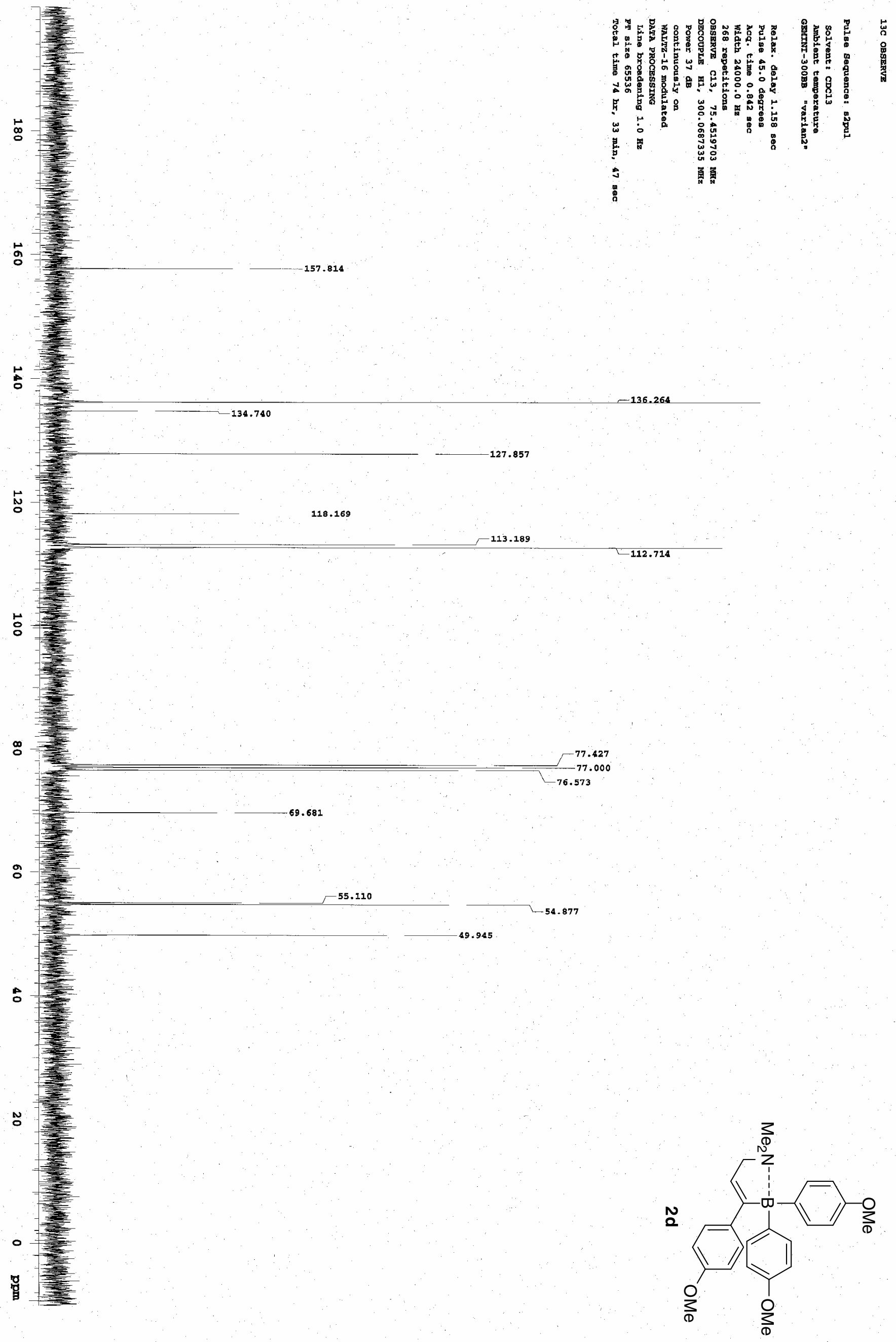



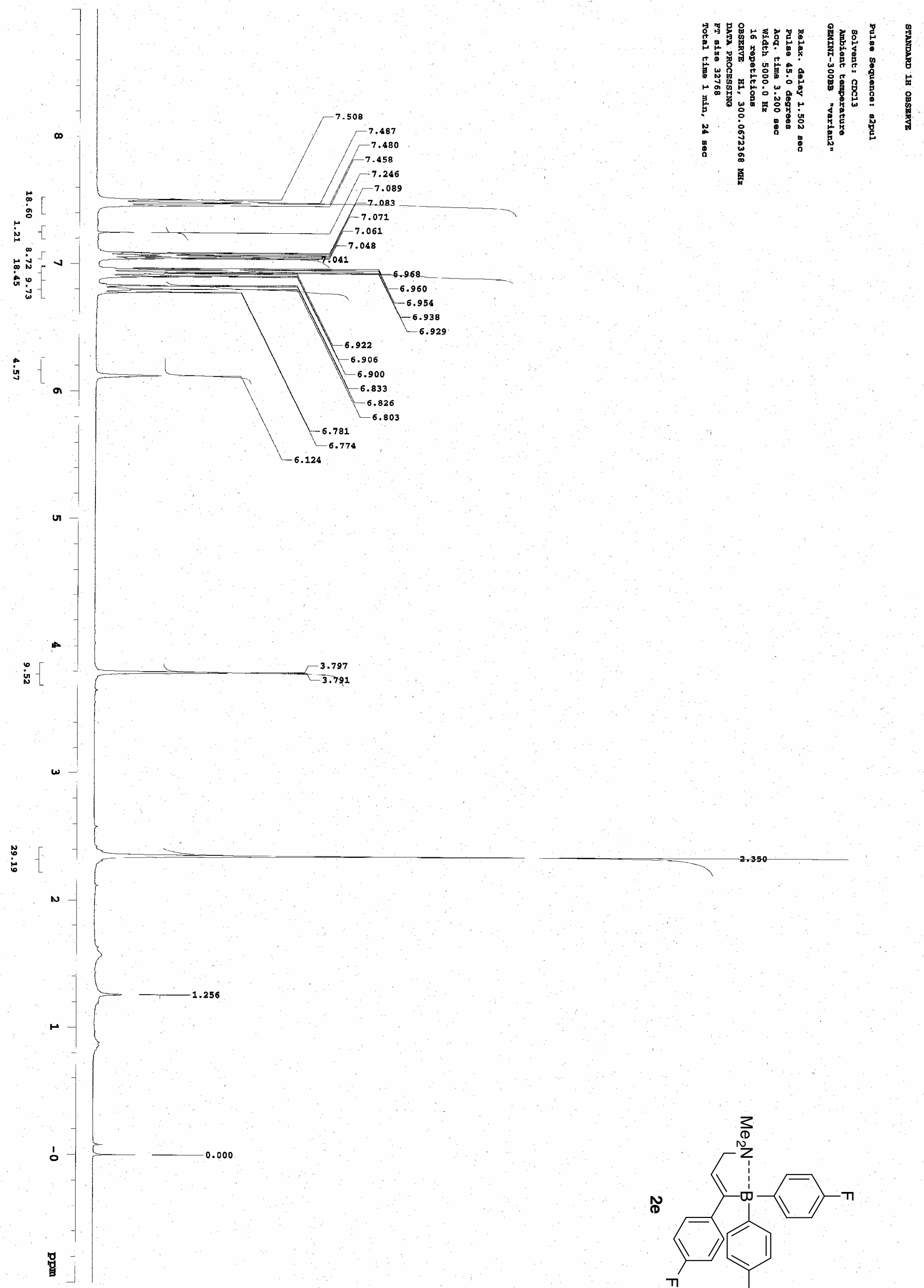


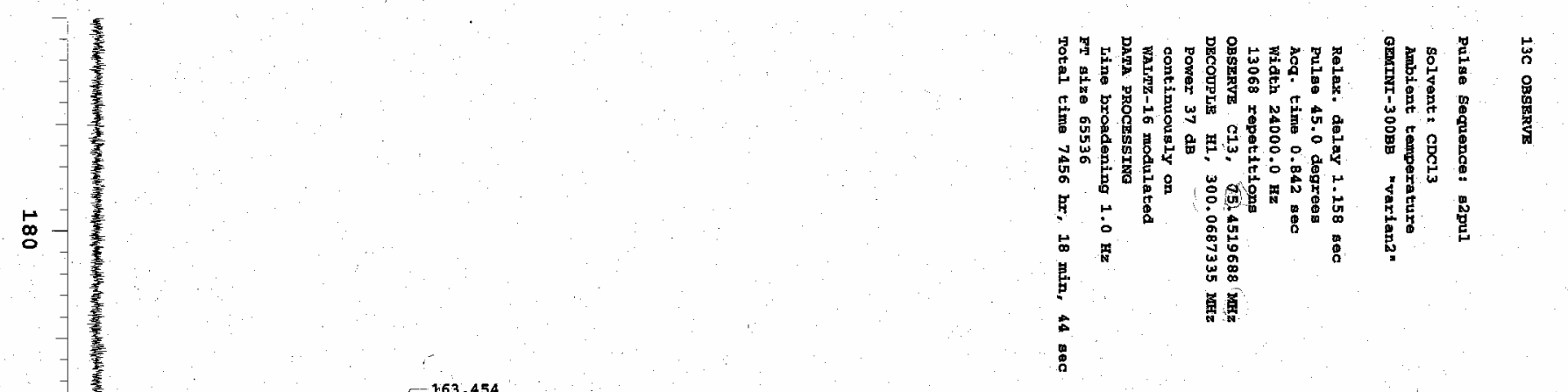

응

占

.

$\overrightarrow{0}$

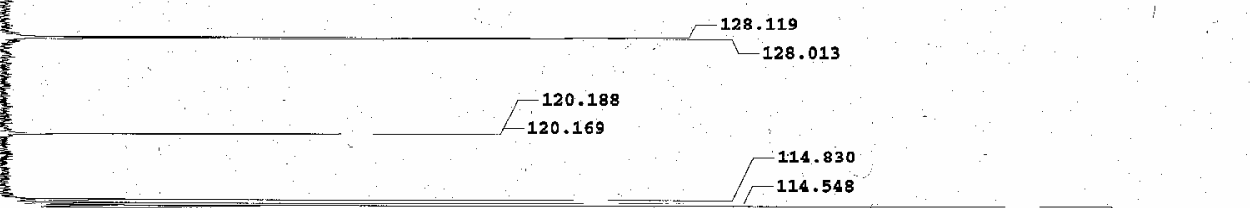

홍

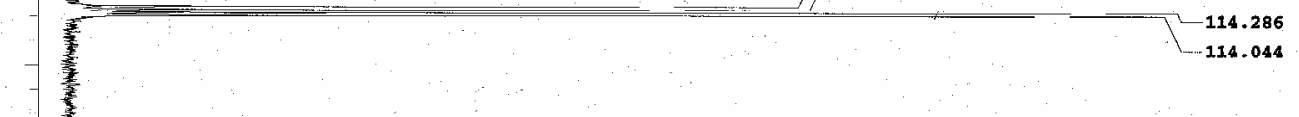

o

$-137.749$

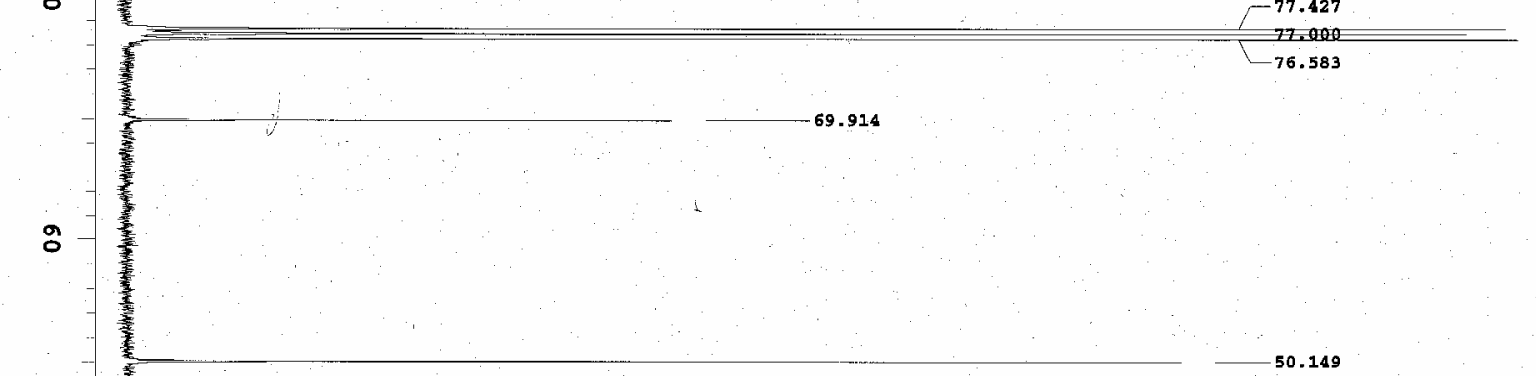

s

-

$-163.115$

$-138.507$ 


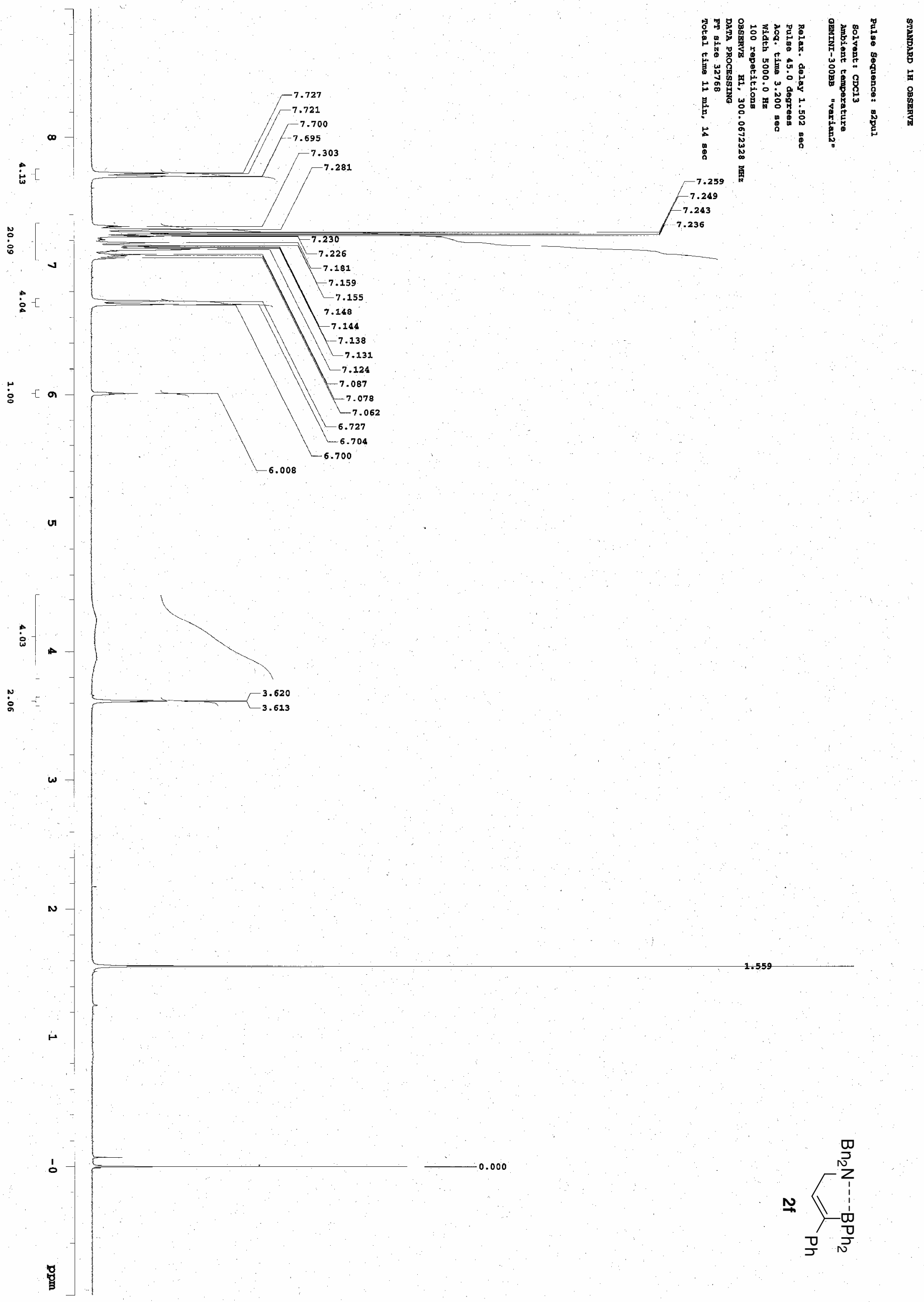




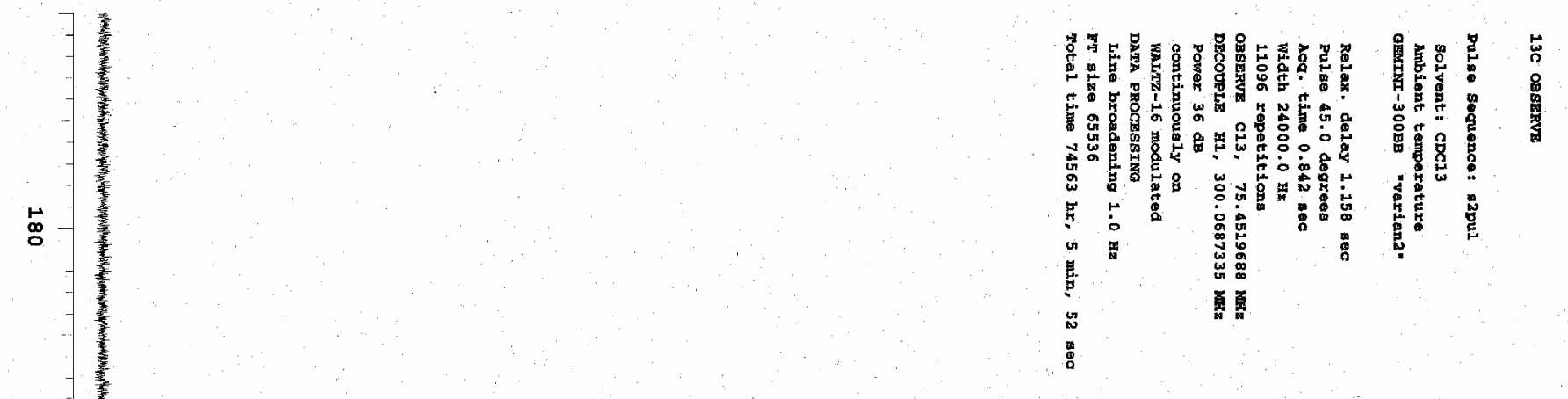

응
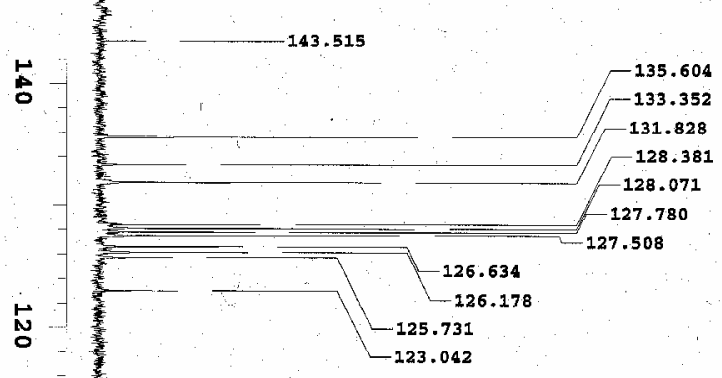

卒

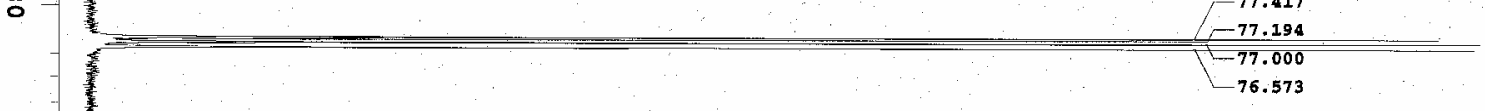

응

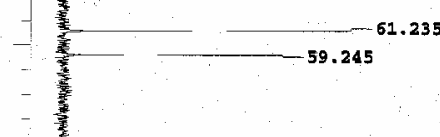

吕 -

1
0
0
0
0
0
0
0

$\stackrel{\sim}{\rightarrow}$

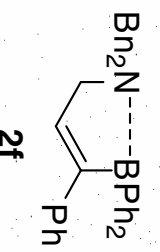




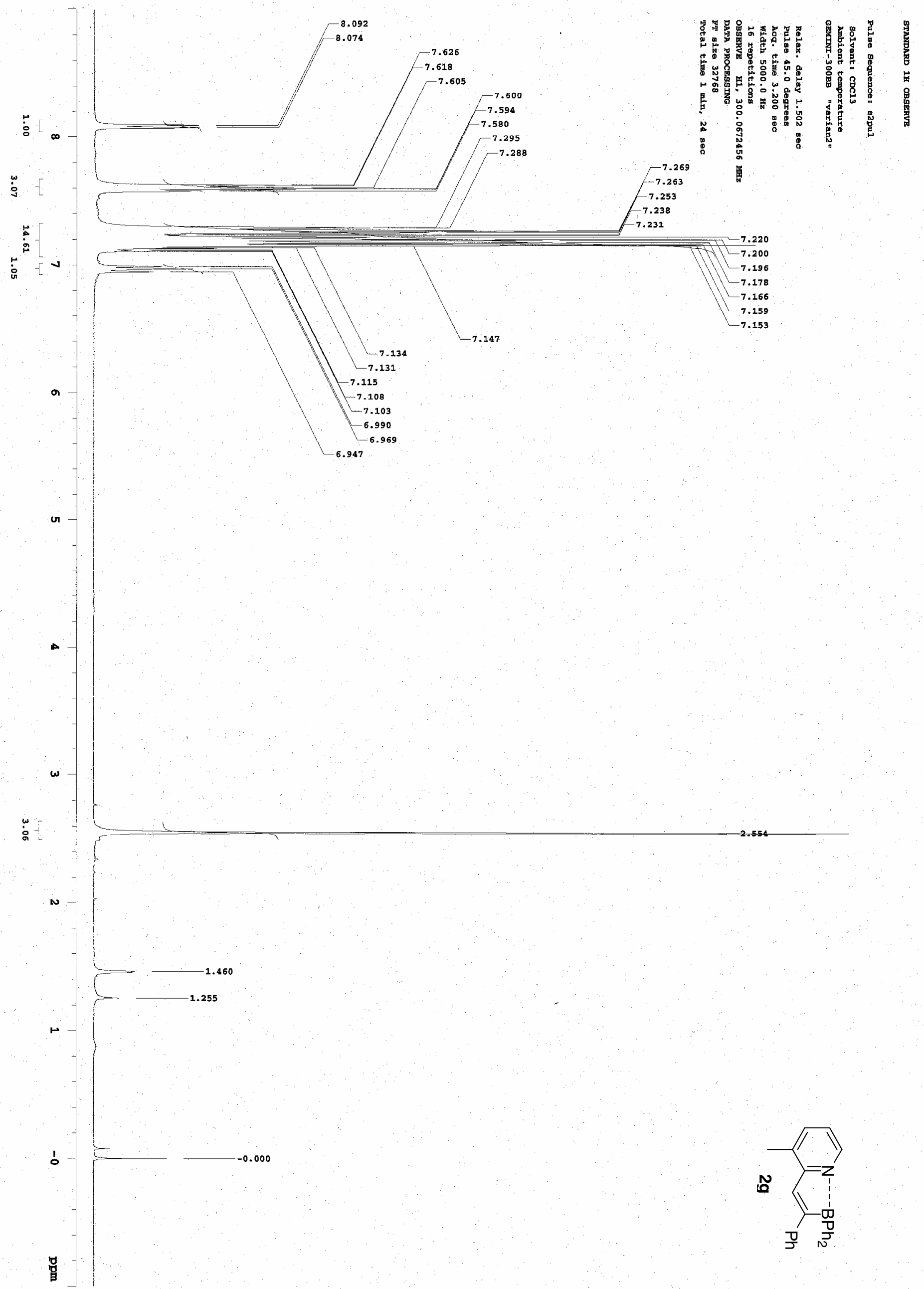




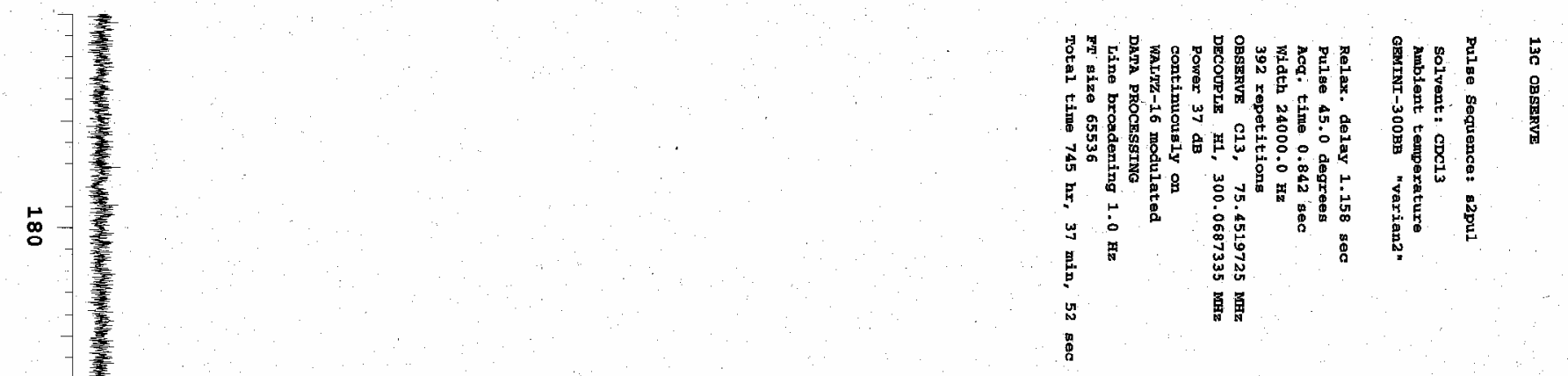

응 159.135

: $-140.487$

芯

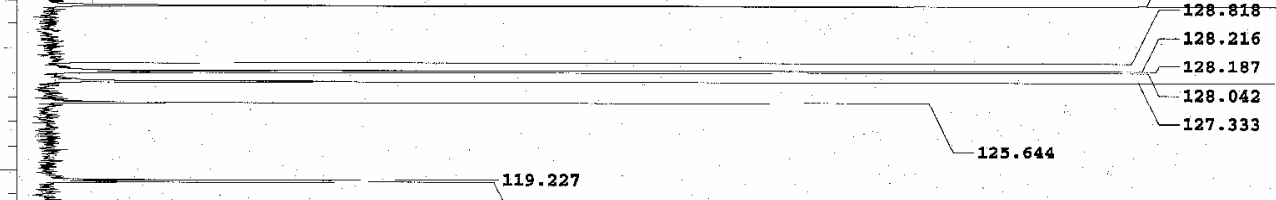

:

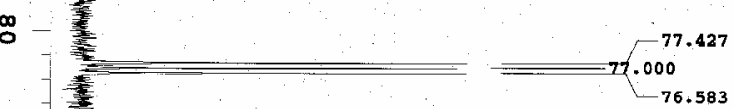

a

-$$
-119.053
$$$$
\text { 妻 }
$$

翠
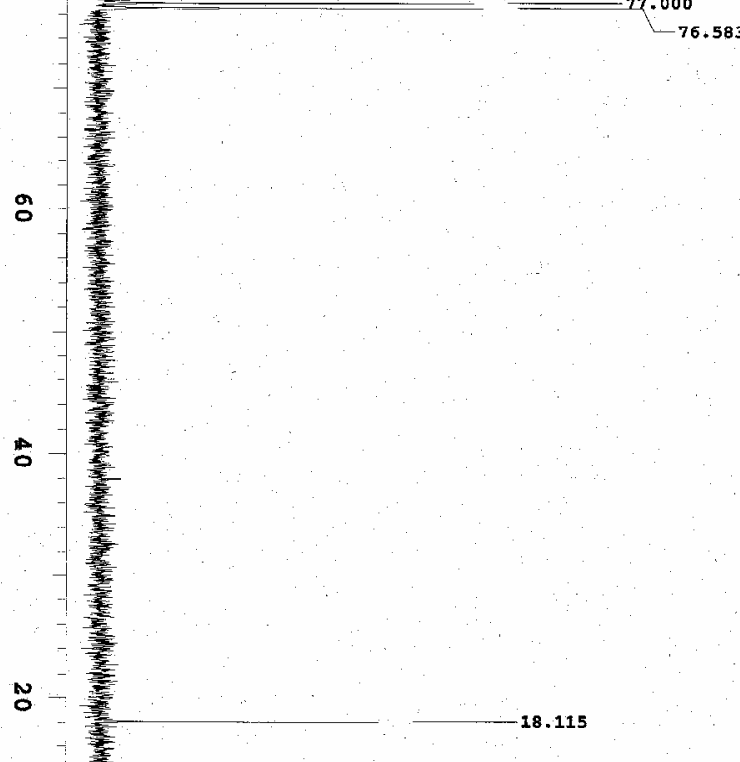

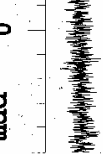

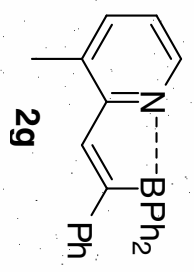




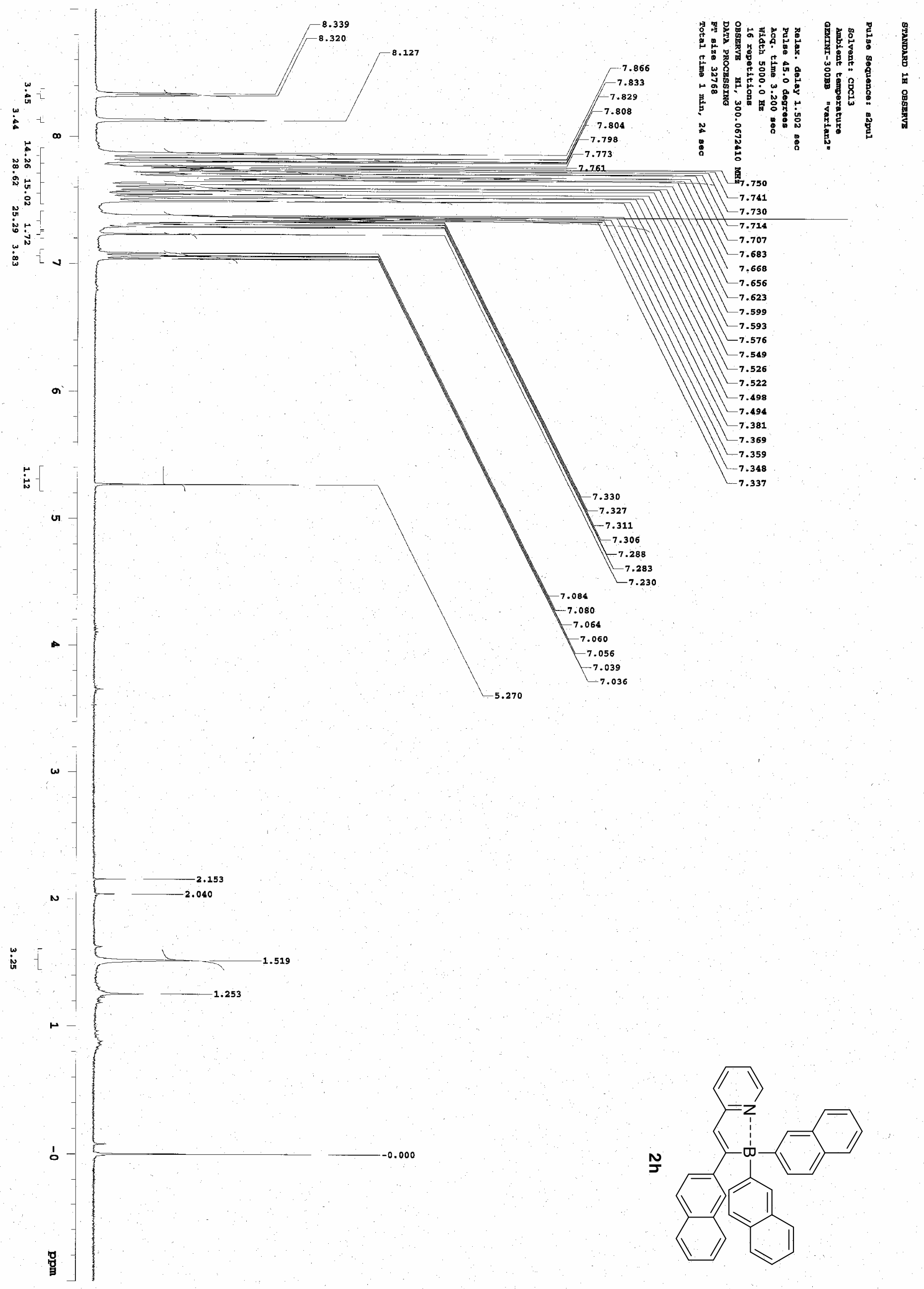




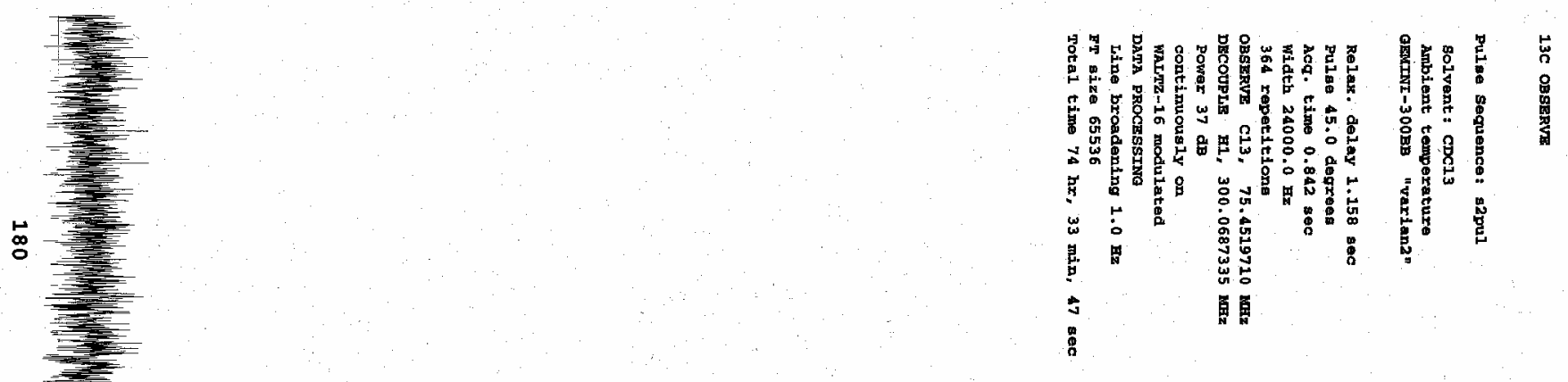

옹 $-160.261$

:

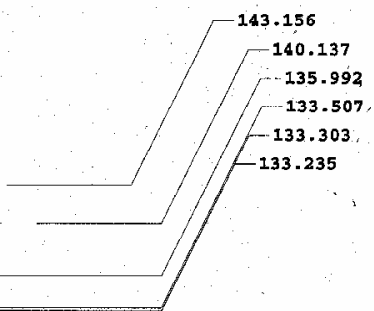

132.012

128.663

$-128.595$

$-127.498$

127.343

岕

$-127.304$

126.440

$-126.042$

124.955

124.955
-124.741

$-121.683$

119.

:

77.417

응

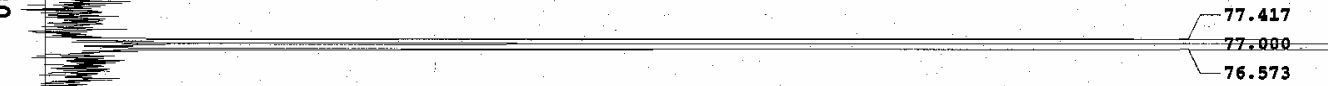

A

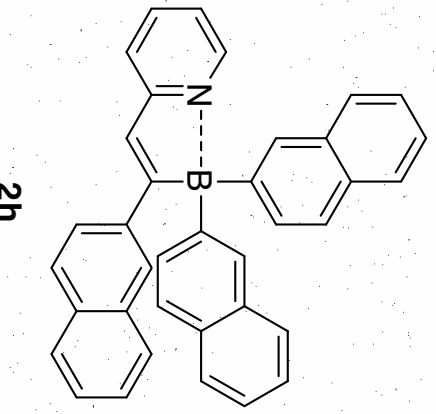




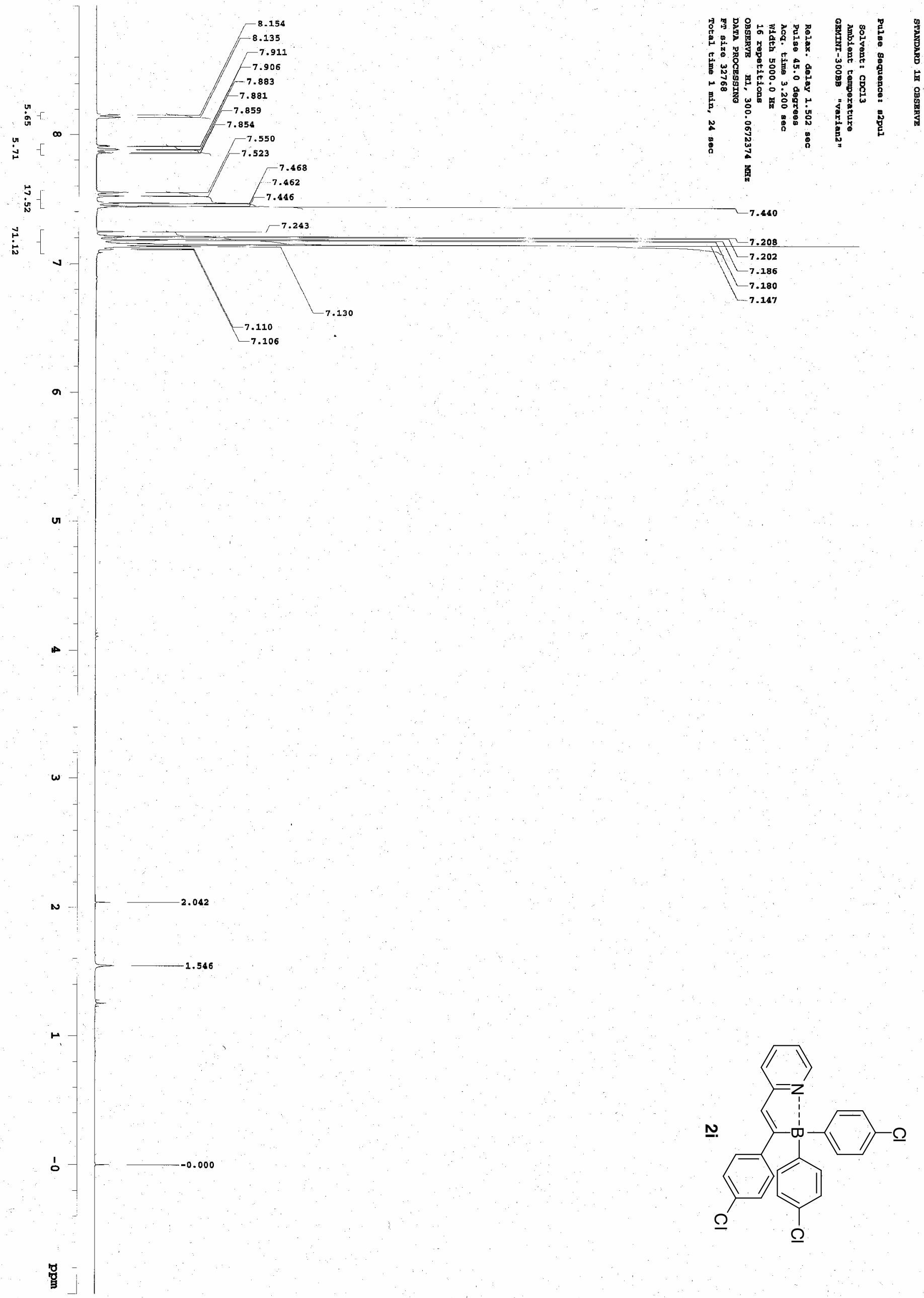




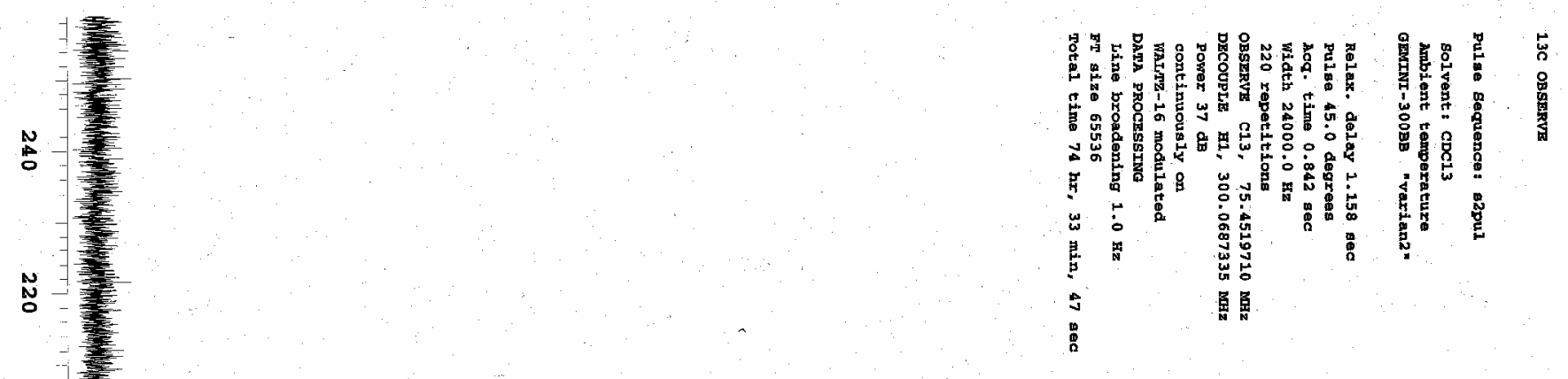

$\stackrel{N}{\circ}$

品

응 $-159.911$

:

$-142.748$

136.487
-130.516

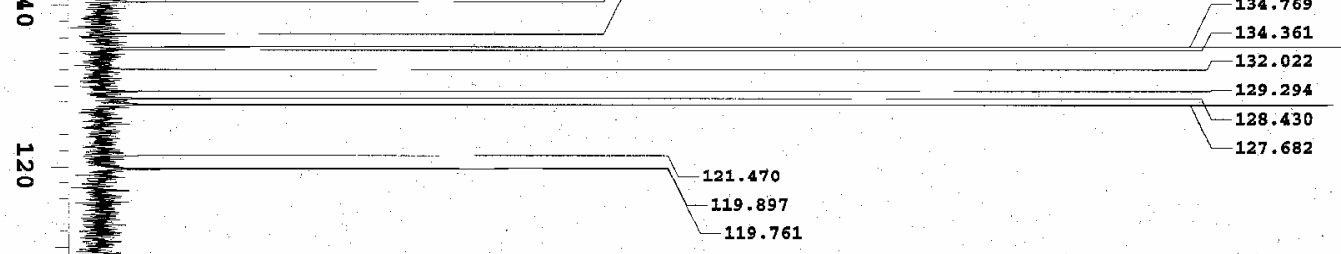

品 77. 417

$\leftarrow_{76.573}$

a

:

旁

:

ฉั

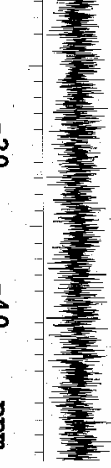

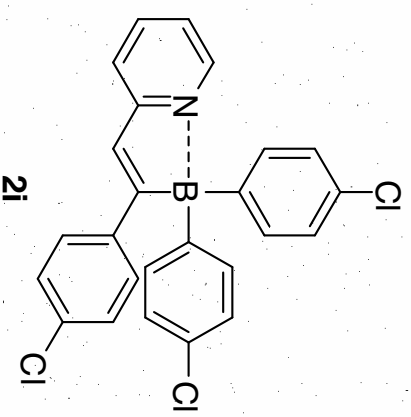




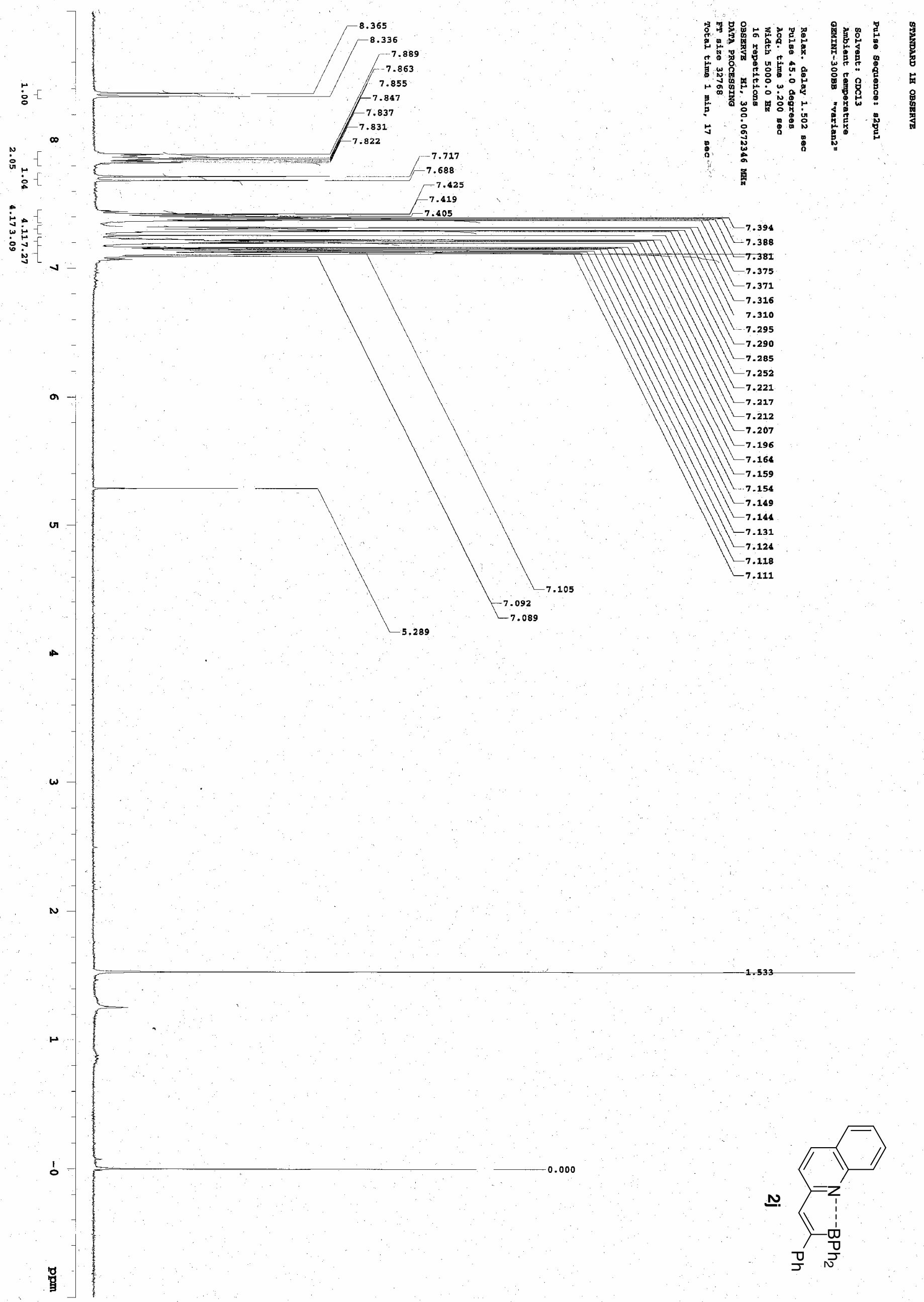



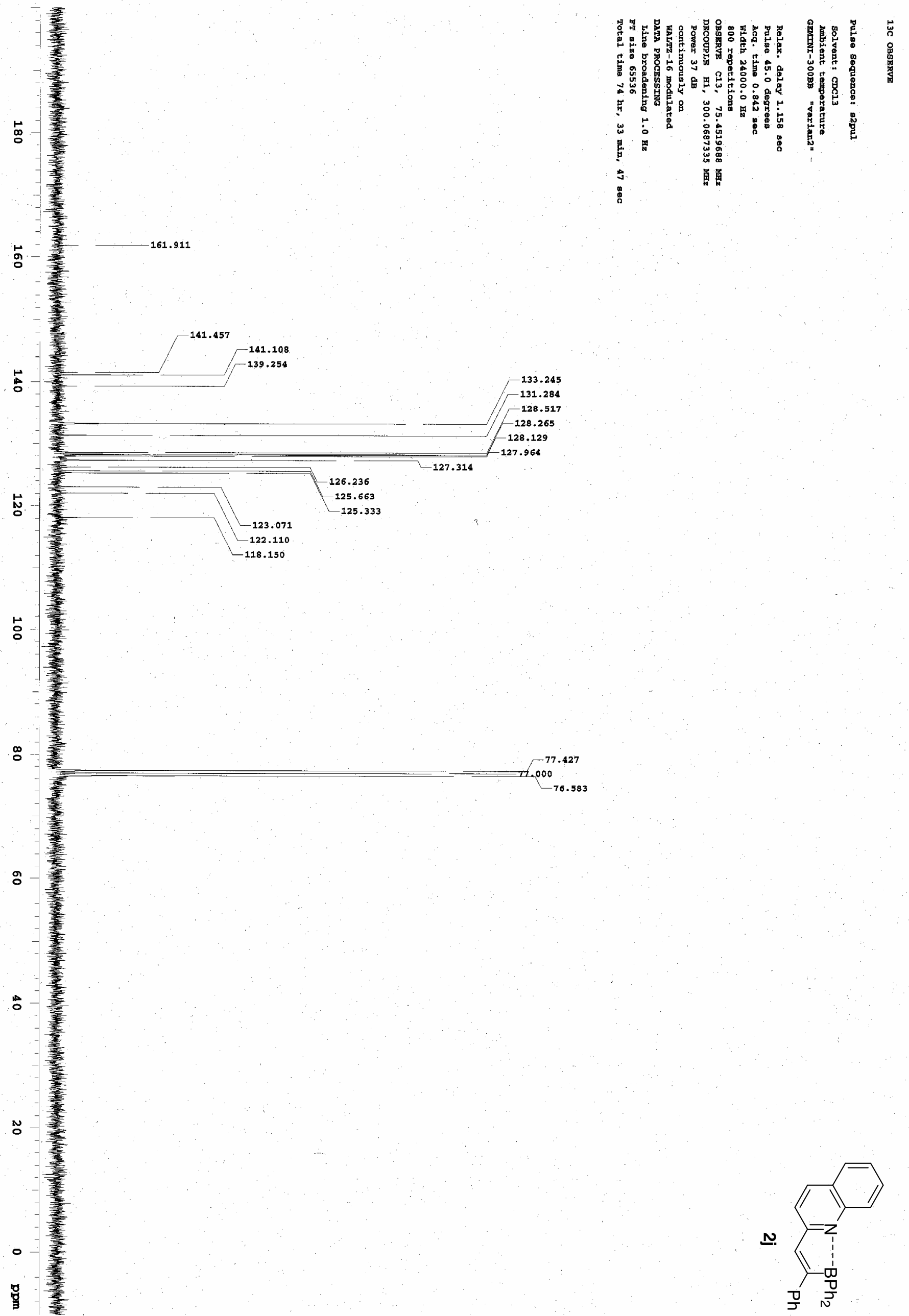


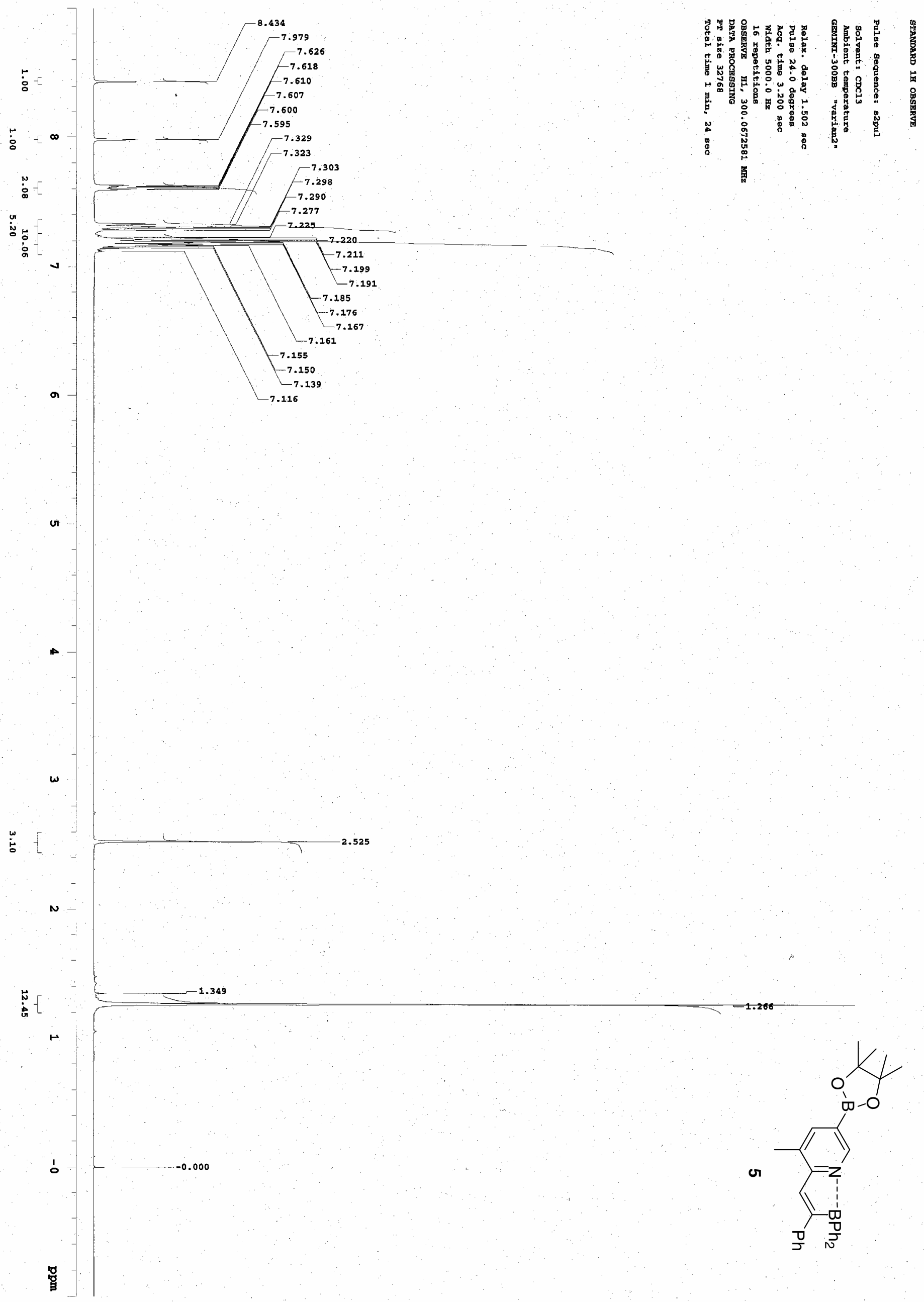




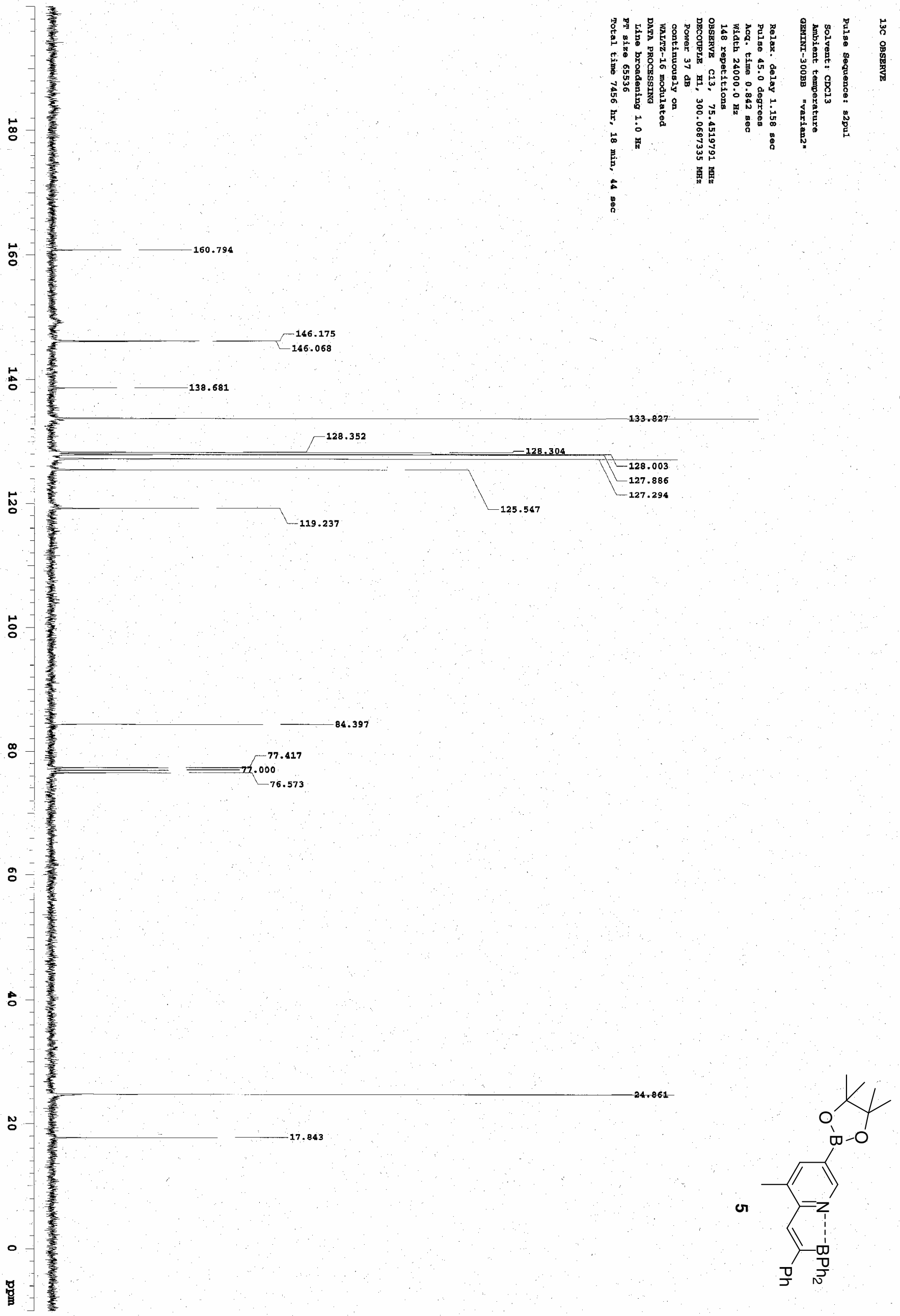




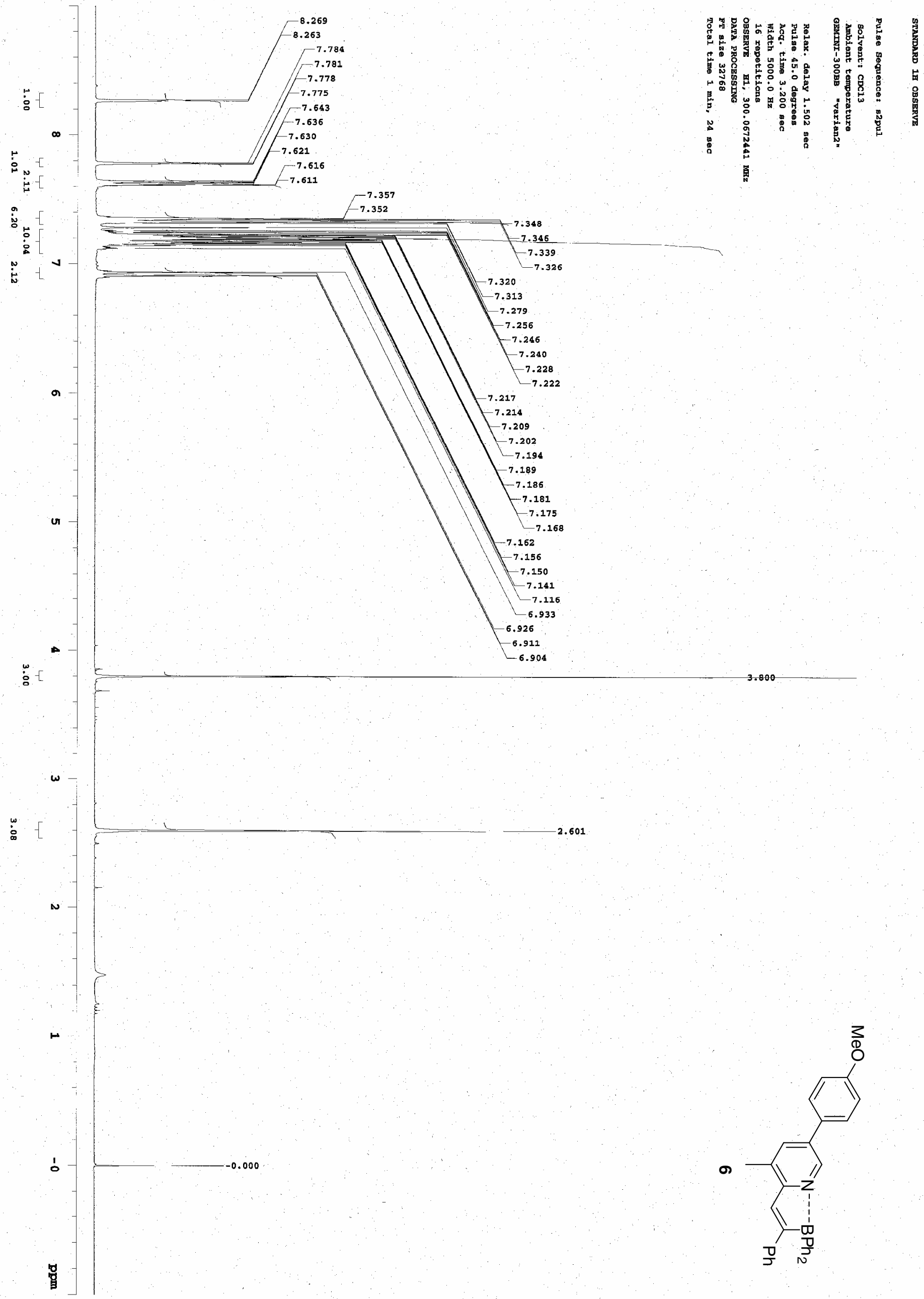



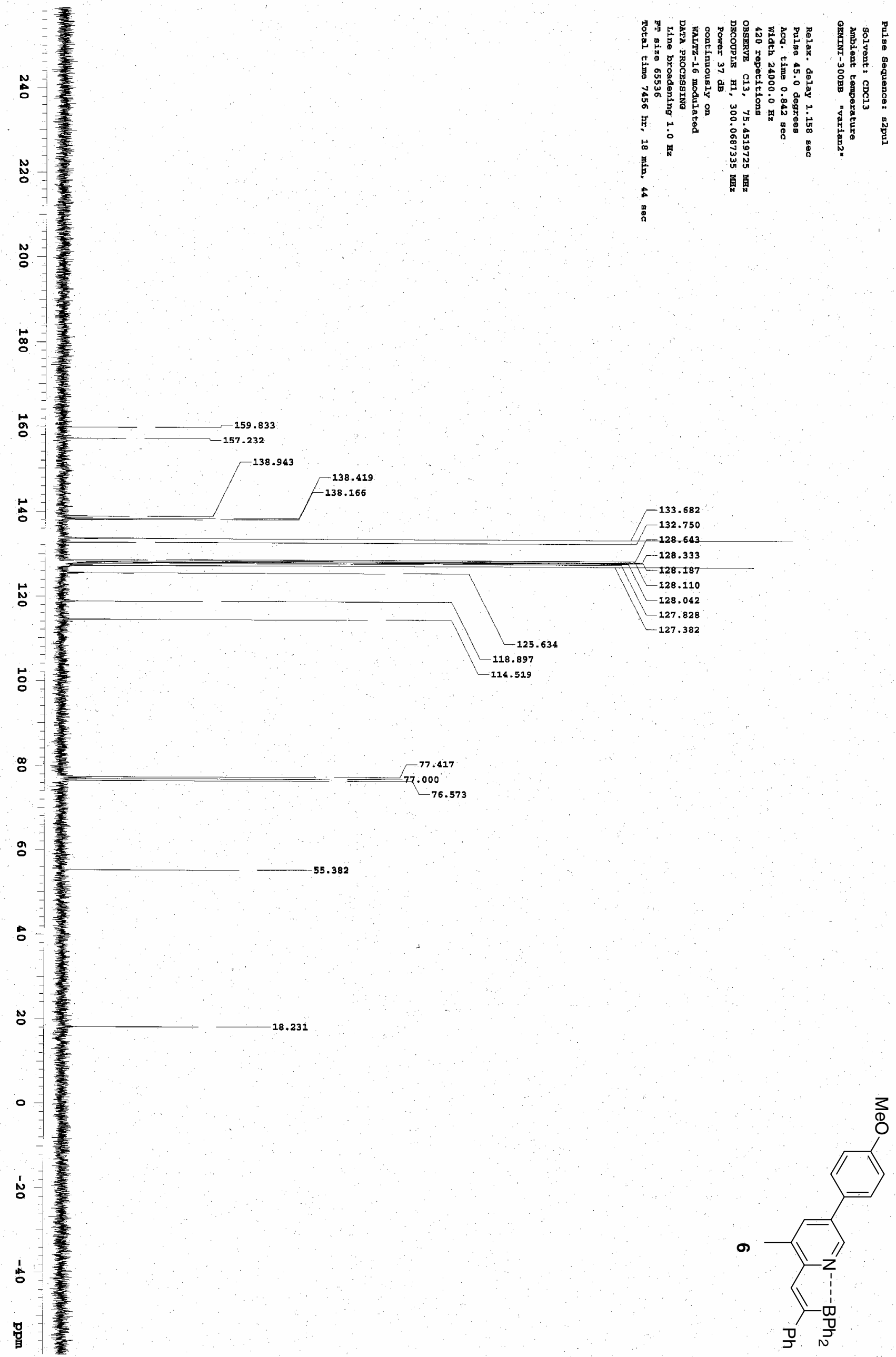

$-128.643$

128.333
-128.187

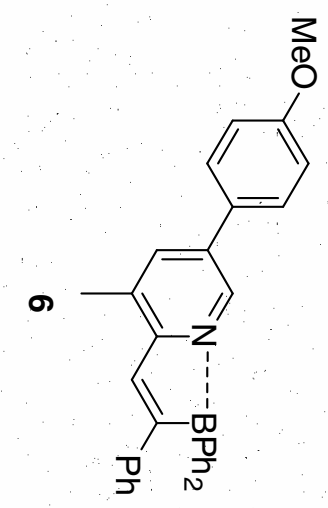

